\title{
Conjunctival changes induced by prostaglandin analogues and timolol maleate: a histomorphometric study
}

\author{
Alterações conjuntivais induzidas por análogos de prostaglandinas e maleato \\ de timolol: estudo histomorfométrico
}

\author{
Heloisa Helena Abil Russ ${ }^{1}$ \\ Vital Paulino Costa ${ }^{2}$ \\ Fabiano Montiani Ferreira ${ }^{3}$ \\ Sílvia Reg'ina Valgas ${ }^{4}$ \\ Mario Adolfo Correa Neto ${ }^{5}$ \\ Eduardo von Linsing'en Strobel ${ }^{6}$ \\ Jessé Henrique Truppel ${ }^{7}$
}

\section{ABSTRACT}

Purpose: To compare histological changes induced by antiglaucoma medications in the rabbit conjunctiva. Methods: Fifty New Zealand rabbits were divided in 5 groups of 10 animals. The left eyes were treated daily with one drop of bimatoprost $0.03 \%$, travoprost $0.004 \%$, latanoprost $0.005 \%$, timolol maleate $0.5 \%$ or artificial tears containing benzalkonium chloride (BAK) for 30 days. The right eyes served as controls. Superior limbic conjunctival biopsies were performed at the $8^{\text {th }}$ and $30^{\text {th }}$ day in 5 rabbits of each group. The conjunctiva was fixed with $10 \%$ formaldehyde, followed by $\mathrm{HE}$ and PAS staining. Morphohistometric quantitative analyses were performed to evaluate the following parameters: inflammatory infiltrate, epithelial thickness, number of goblet cells, diameter and number of blood vessels. Results: At the $8^{\text {th }}$ and $30^{\text {th }}$ posttreatment days, all groups, except one that received artificial tears, exhibited a diffuse inflammatory infiltrate, composed by lymphocytes and neutrophils, which was denser in the timolol group than in the prostaglandin (PG) analogues groups. At the $30^{\text {th }}$ day, the timolol group also showed an increased subepithelial collagen density and a significant increase in epithelial thickness $(p=0.0035)$. The goblet cell density was significantly increased at the $8^{\text {th }}$ day in the group treated with travoprost $(p=0.0006)$, and at the $30^{\text {th }}$ day in those treated with bimatoprost $(p=0.0021)$ and latanoprost $(p=0.009)$. Conclusions: Although a moderate, diffuse inflammatory infiltrate was observed in PG-treated eyes, no changes in conjunctival epithelial thickness or subconjunctival collagen density were observed with these medications, suggesting that these drugs induce fewer changes than timolol maleate in the rabbit conjunctiva.

Keywords: Prostaglandins, synthetic; Timolol/therapeutic use; Conjunctiva; Glaucoma/ drug therapy; Rabbits

\section{INTRODUCTION}

Glaucoma is a chronic multifactorial progressive optic neuropathy requiring long-term treatment with topical hypotensive medications ${ }^{(1)}$. Many classes of drugs are currently available to treat glaucoma, including cholinergic agents, beta-blockers, alpha adrenergic agonists, carbonic anhydrase inhibitors, and more recently prostaglandin (PG) analogues ${ }^{(2)}$.

PG analogues increase uveoscleral outflow and may reduce intraocular pressure up to $40 \%$ of its initial value. Systemic side effects induced by 
topical PG analogues are rare. On the other hand, iris hyperpigmentation, excessive eyelash growth and conjunctival hyperemia are reported as local side effects caused by these $\operatorname{drugs}^{(3-6)}$. Moreover, conditions that suggest stimulation or reactivation of the ocular inflammatory response, such as anterior uveitis and cystoid macular edema, were also associated with the use of PG analogues ${ }^{(7-12)}$.

In patients treated with topical medication, the conjunctiva acts like a semi-permeable membrane that, along with the cornea, allows absorption of ocular hypotensive drugs. On the other hand, the conjunctiva responds to chronic treatment with antiglaucoma drugs with inflammation, scar formation, keratinization and neovascularization, which may directly affect its architecture and function ${ }^{(13)}$. Recently, several studies have evaluated the conjunctival changes induced by latanoprost ${ }^{(14-16)}$, but there is insufficient information about the consequences of the use of other PG analogues, such as travoprost and bimatoprost.

Previous studies with patients who received prolonged topical medication showed that both hypotensive drugs and its preservatives (benzalkonium chloride - BAK) may increase the number of inflammatory cells and fibroblasts in the substantia propria of the conjunctiva and reduce the number of goblet cells, inducing ocular surface modifications expressed as dry eye $\mathrm{e}^{(13,17-18)}$. The length of administration, concentration and amount of medication were related to severity of side effects ${ }^{(17-18)}$. Furthermore, there is strong evidence suggesting that these changes may increase the risk of failure of trabeculectomy ${ }^{(13,18-21)}$. However, most pieces of information on this topic were published before the introduction of PG analogues.

The purpose of this study was to compare histomorphometric changes induced by latanoprost, travoprost and bimatoprost with those induced by timolol maleate and BAK in rabbit conjunctiva.

\section{METHODS}

Fifty female New Zealand rabbits with similar age and weight were selected and divided into 5 groups of 10 animals. The rabbits were treated with bimatoprost $0.03 \%$ (Lumigan $^{\mathrm{TM}}$, Allergan, Irvine-CA, USA) $(n=10)$, travoprost $0.004 \%$ (Trava$\tan ^{\mathrm{TM}}$, Forth Worth, TX, USA) $(\mathrm{n}=10)$, latanoprost $0.005 \%$ $\left(\right.$ Xalatan $^{\mathrm{TM}}$, Pfizer, New York, USA) $(\mathrm{n}=10)$, timolol maleate $0.5 \%$ (Timoptic-XE $^{\mathrm{TM}}$, Merck, Sharp \& Dome, New Jersey, USA) $(n=10)$ or artificial tears (hypromellose and dextran 70) (Lacribell $^{\mathrm{TM}}$, Latinofarma, São Paulo, Brazil) $(\mathrm{n}=10)$. The drop volume was $27.05 \mu \mathrm{l}$ for bimatoprost, $24.26 \mu \mathrm{l}$ for travoprost, $23.81 \mu \mathrm{l}$ for latanoprost, $27.9 \mu \mathrm{l}$ for timolol maleate and $28.3 \mu \mathrm{l}$ for artificial tears. One daily drop of the selected substance was instilled onto the left cornea of each animal at 8:00 $\mathrm{AM}$ for 30 days, while the right eye served as a control. BAK was the preservative in all tested eye drops at the following concentrations: bimatoprost (BAK 0.005\%), travoprost (BAK $0.015 \%$ ), latanoprost (BAK $0.02 \%$ ), timolol maleate (BAK
$0.01 \%$ ), and artificial tears (BAK 0.006\%). Limbic superior conjunctival biopsies ( $5 \mathrm{~mm} \times 5 \mathrm{~mm}$ ) were performed at the $8^{\text {th }}$ and $30^{\text {th }}$ days in 5 rabbits of each group, except for the BAK group, where biopsies were performed only at the $30^{\text {th }}$ day. After conjunctival biopsies were performed at the $8^{\text {th }}$ day, these animals were excluded from the study, and the remaining animals underwent biopsies at the $30^{\text {th }}$ day. A conscious attempt to perform the conjunctival biopsy consistently at the same peri-limbic location was made. All samples were taken at the same time of the day (4:00 - 5:00 PM), maintaining the same interval between time of instillation and time of biopsy for all groups.

The conjunctiva was immediately fixed with $10 \%$ formaldehyde for 24 hours, followed by routine paraffin embedding and staining with HE (hematoxylin-eosin) and PAS (periodic acid-Schiff). During the embedding procedure, an effort was made to ensure that the histological samples were placed with the epithelium facing the bottom of the histological cassette in order to avoid cuts that were not tangential to the plane of the tissue.

Morphohistometric quantitative analyses were performed with the software Image Pro-Plus version 4 (IP4) (Media Cybernetics, Silver Spring, MD). Digital images were acquired under 400x magnification and stored using the same software. Subsequently, two segments of $200 \mu \mathrm{m}$ of length and with $5 \mu \mathrm{m}$ of thickness of epithelial tissue were randomly selected from each examined field of all slides. These same-sized linear segments allowed measurement of the following parameters: number and diameter of blood vessels, number of goblet cells and conjunctival epithelium thickness. Diameter and thickness were measured using default pre-programmed virtual tools for tissues. Number of blood vessels and goblet cells were manually counted using a $200-\mu \mathrm{m}$ virtual ruler.

Optical qualitative microscopy evaluation was made in linear conjunctival segments of $200 \mu \mathrm{m}$ using a virtual ruler on digital images. The intensity of inflammatory infiltrate was analyzed qualitatively (absent, mild, moderate or severe) in all biopsy samples comparing pictures taken from 200 and 400x fields of each slide. The histologist (FMF) responsible for measuring all parameters was masked to the medication group of the rabbit. Repeat masked measurements performed by the same examiner (FMF) resulted in low coefficients of variability.

One-way ANOVA with a significance level of 5\% was used to compare continuous variables. If any statistically significant difference was found, the data were further analyzed using post hoc comparisons with Fisher's test (for comparisons of up to three groups) or Tukey-Kramer test (comparisons of more than 3 groups). Differences were deemed statistically significant when $p$ values were lower than 0.05 .

The experimental procedures used in the investigation followed the ARVO Statement for the Use of Animals in Ophthalmic and Vision Reasearch, and the study was appro- 
ved by the Committee Review Boards of the Universidade de São Paulo and the Hospital Universitário Evangélico de $\mathrm{Cu}$ ritiba (CAPPESQ nํำ161/05).

\section{RESULTS}

A significant increase in goblet cells was detected at the $8^{\text {th }}$ day in the travoprost group $(p=0.0006)$. After 30 days of treatment, there was a significant increase in the number of goblet cells in the bimatoprost $(p=0.0021)$ and latanoprost $(p=0.009)$ groups. There were no significant changes in the number of goblet cells in the timolol and BAK groups $(p>0.05)$ (Table 1) (Figures 1 and 2).

There was a significant increase in epithelial thickness $(p=0.0035)$ at the $30^{\text {th }}$ day in the group treated with timolol maleate (Table 1). Figure 3 illustrates the increased conjunctival epithelial thickness observed in this group, along with a higher number of epithelial layers. A statistically significant rise in the mean number of blood vessels was observed at the $30^{\text {th }}$ day in the latanoprost $(p=0.0205)$ and timolol groups $(p=0.0012)$ (Table 1). There was an overall trend, though not statistically significant, toward reduced vascular diameter in the travoprost group at the $8^{\text {th }}$ day $(p=0.0758)$, which became statistically significant at the $30^{\text {th }}$ day $(p=0.0348)$ (Table 1$)$. No significant differences were observed between the BAK and control groups regarding epithelial thicknesses and number of blood vessels.

There were no significant differences between drop volume of all medications (mean of $25.668 \mu 1$, standard deviation of $2.051 \mu \mathrm{l}$ and standard error of $0.837 \mu \mathrm{l}$ ).

In the control group and in the group treated with artificial

\begin{tabular}{|c|c|c|c|c|c|c|c|c|c|c|c|c|c|c|c|}
\hline & \multicolumn{15}{|c|}{ Table 1. Results of all treated groups comparing to controls at day $8^{\text {th }}$ and $30^{\text {th }}$} \\
\hline & \multicolumn{5}{|c|}{ G1 (Bimatoprost) } & \multicolumn{5}{|c|}{ G2 (Travoprost) } & \multicolumn{5}{|c|}{ G3 (Latanoprost) } \\
\hline & \multicolumn{2}{|c|}{ OD } & \multicolumn{2}{|c|}{$\mathrm{OE}$} & \multirow[t]{2}{*}{$p$ value } & \multicolumn{2}{|c|}{ OD } & \multicolumn{2}{|c|}{$\mathrm{OE}$} & \multirow[t]{2}{*}{$p$ value } & \multicolumn{2}{|c|}{ OD } & \multicolumn{2}{|c|}{$\mathrm{OE}$} & \multirow{2}{*}{$p$ value } \\
\hline & M & $\pm \mathrm{SD}$ & M & \pm SD & & M & \pm SD & M & \pm SD & & M & \pm SD & M & \pm SD & \\
\hline \multicolumn{16}{|c|}{ Goblet Cells (n) } \\
\hline $8^{\text {th }}$ day & 8.80 & 2.70 & 11.00 & 3.68 & 0.145 & 5.40 & 2.37 & 10.40 & 2.95 & 0.001 & 8.00 & 2.00 & 8.40 & 2.88 & 0.732 \\
\hline $30^{\text {th }}$ day & 7.50 & 1.65 & 10.30 & 1.82 & 0,002 & 8.40 & 3.10 & 7.66 & 2.73 & 0.594 & 7.20 & 1.54 & 9.70 & 2.21 & 0.009 \\
\hline \multicolumn{16}{|c|}{$\begin{array}{l}\text { Epithelial } \\
\text { thickness }\end{array}$} \\
\hline $8^{\text {th }}$ day & 15.23 & 3.84 & 11.29 & 4.37 & 0.151 & 13.00 & 2.83 & 11.21 & 2.97 & 0.552 & 8.74 & 0.34 & 12.83 & 3.35 & 0.201 \\
\hline $30^{\text {th }}$ day & 13.06 & 4.18 & 12.81 & 3.96 & 0.945 & 15.42 & 3.77 & 13.49 & 4.24 & 0.588 & 10.70 & 2.51 & 14.12 & 4.00 & 0.371 \\
\hline \multicolumn{16}{|c|}{ Vessels (n) } \\
\hline $8^{\text {th }}$ day & 1.40 & 1.67 & 2.40 & 2.41 & 0.468 & 1.20 & 1.79 & 1.60 & 0.55 & 0.645 & 1.50 & 0.58 & 1.60 & 1.34 & 0.894 \\
\hline $30^{\text {th }}$ day & 1.20 & 0.84 & 3.80 & 3.35 & 0.130 & 0.80 & 1.30 & 1.80 & 1.30 & 0.260 & 1.00 & 1.00 & 4.80 & 2.78 & 0.021 \\
\hline \multicolumn{16}{|c|}{$\begin{array}{l}\text { Vessels } \\
\text { (diameter) }\end{array}$} \\
\hline $8^{\text {th }}$ day & 15.05 & 8.14 & 17.29 & 7.17 & 0.658 & 10.95 & 9.08 & 19.73 & 4.65 & 0.076 & 18.09 & 2.43 & 4.54 & 6.45 & 0.288 \\
\hline $30^{\text {th }}$ day & 13.89 & 6.85 & 17.66 & 5.15 & 0.324 & 23.97 & 8.15 & 13.72 & 2.61 & 0.035 & 13.88 & 1.92 & 19.15 & 9.01 & 0.275 \\
\hline
\end{tabular}

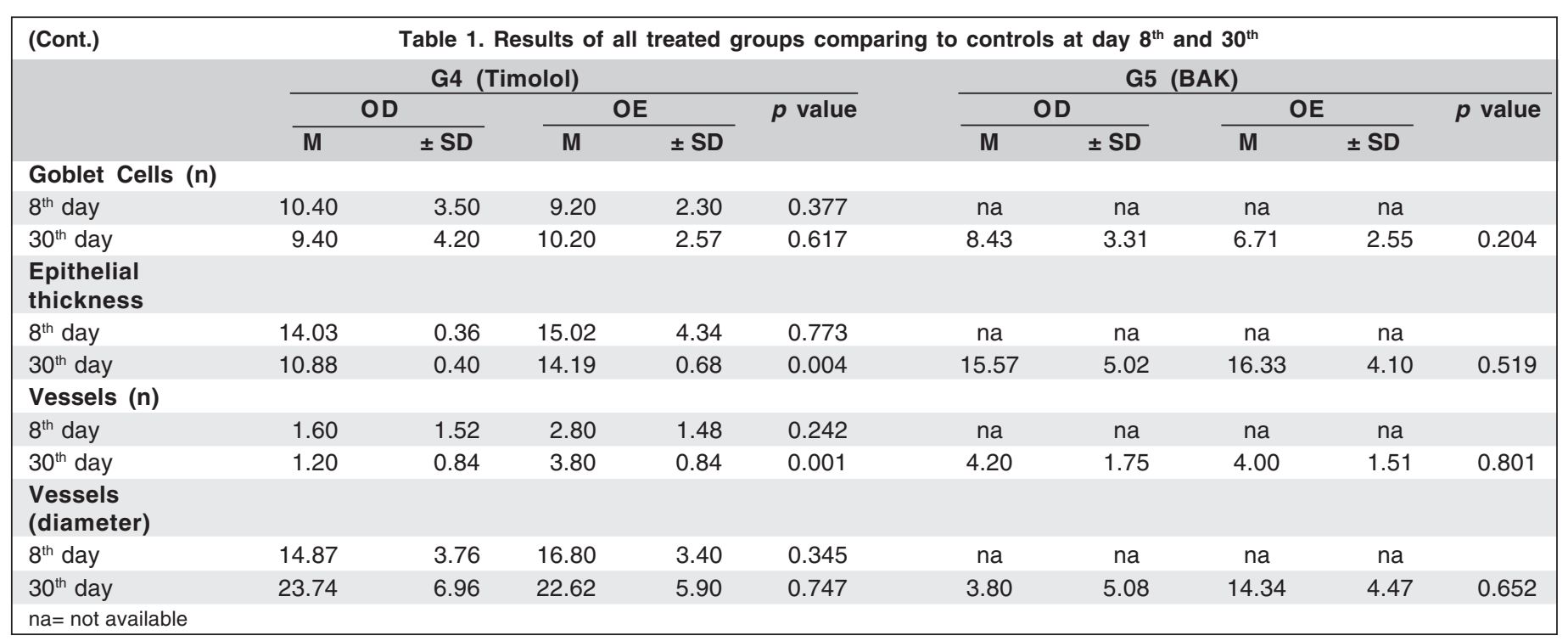




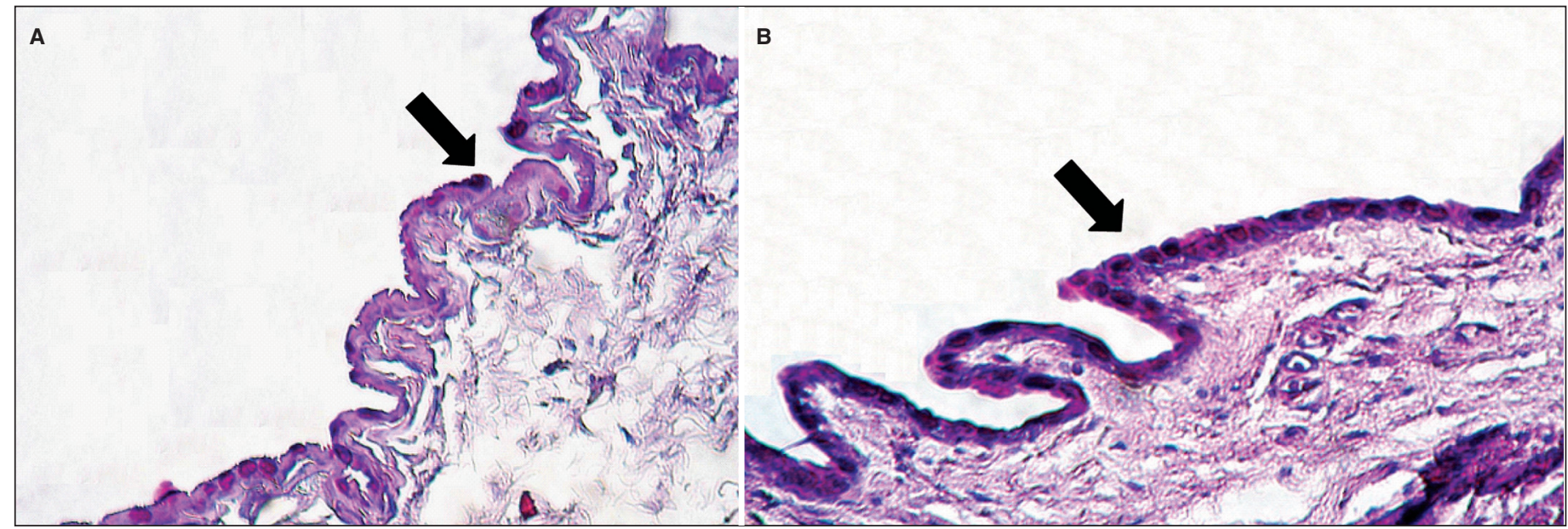

Figure 1 - Photomicrographs (400x) of conjunctival samples, PAS staining: A) from the control eye (OD) of the travoprost group; B) from travoprost treated eye (OS) after 8 days of treatment. Note the marked increase in number of goblet cells on (B).

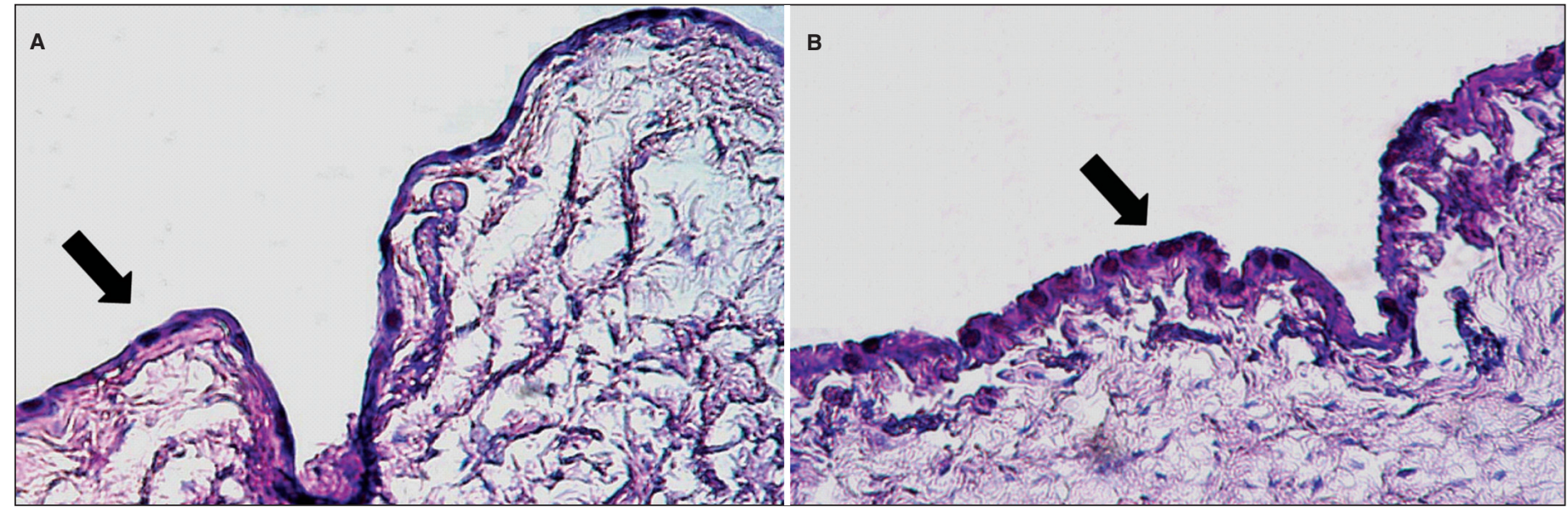

Figure 2 - Photomicrographs (400x) of conjunctival samples, PAS staining. A) from the control eye (OD) of the bimatoprost group; B) from bimatoprost treated eye (OS) after 30 days of treatment. Note the increase in number of goblet cells on (B).

A

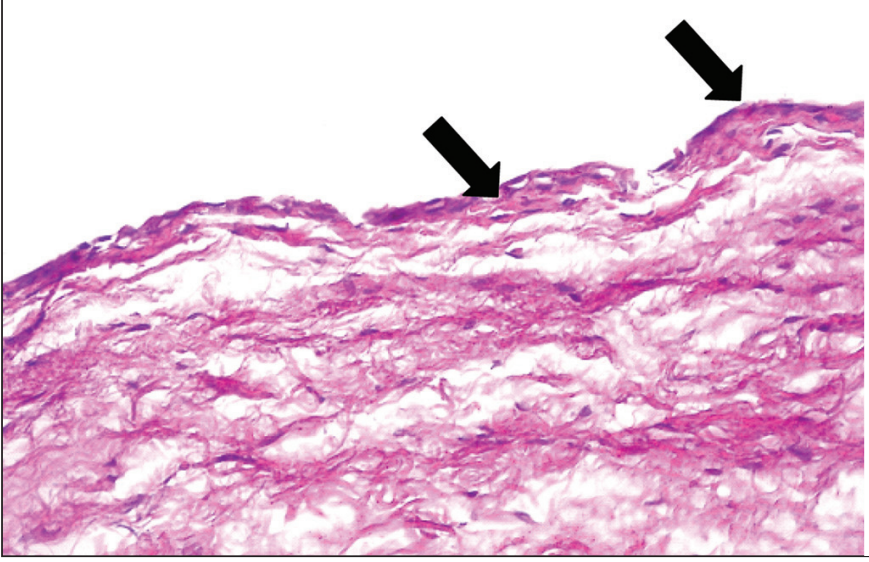

B

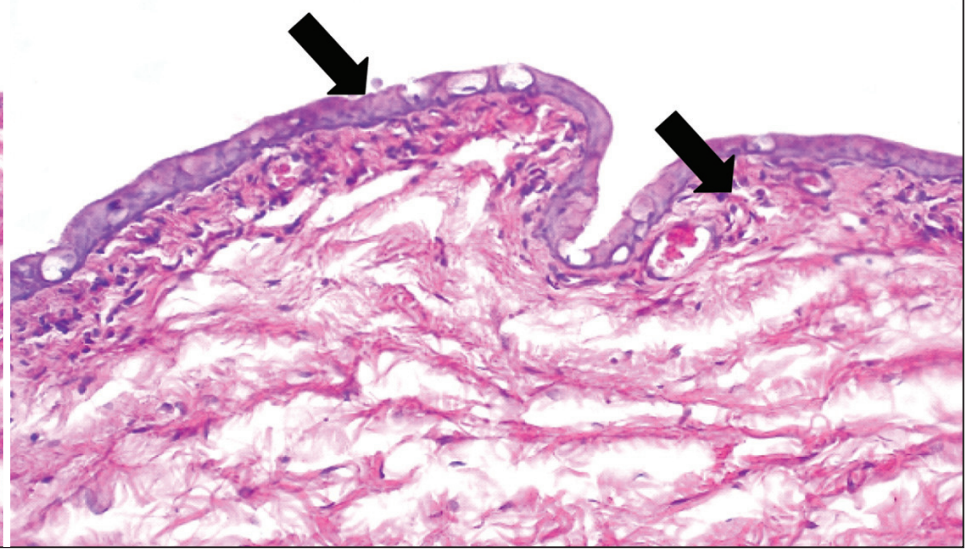

Figure 3 - Photomicrographs (400x) of conjunctival samples, HE staining: A) from the control eye (OD) of the timolol-treated group; B) from the timolol-treated eye (OS). Note marked infiltration with neutrophils on (B). Other changes caused by this drug are visible, such as increased epithelial thickness, congested vessels and a discrete change in the immediate subepithelial collagen architecture. 
tears, the inflammatory infiltrate was focal, of mild intensity, with a preponderance of lymphocytes and rare neutrophils. The eyes treated with antiglaucoma medications, in addition to the same focal inflammatory pattern found in controls, presented a more diffuse inflammatory reaction, consisting of a mixed population of neutrophils and lymphocytes. This pattern was observed in a moderate intensity in the groups that used PG analogues and in severe intensity in the timolol group, which also showed an increase in subepithelial collagen density (Figure 3). There were no significant differences between the samples obtained at the $8^{\text {th }}$ and $30^{\text {th }}$ post-treatment days regarding intensity of the inflammatory reaction.

\section{DISCUSSION}

Strong evidence provided by clinical and experimental studies indicates that the chronic use of antiglaucomatous drugs may induce ocular surface changes, causing discomfort at instillation, conjunctival inflammation, tear film instability, subconjunctival fibrosis, apoptosis of conjunctival epithelium cells and corneal surface alterations ${ }^{(15,18,22-26)}$.

Moreover, these surface changes may increase the risk of failure when patients undergo glaucoma filtering surgery ${ }^{(27-28)}$. Broadway et al. ${ }^{(18)}$ observed that patients using different drops (beta-blocker, miotic + beta-blocker, or miotic + betablocker + sympathomimetic) for more than three years showed conjunctival changes, including an increased number of fibroblasts in the substantia propria. These changes were proportional to the amount of medication instilled and to length of drug administration. The reduction of cellular viability and apoptosis of conjunctival epithelial cells following the use of antiglaucoma medications have also been related to exposure time, number of drugs in use and their concentration, but there is little information available about the influence of PG analogues ${ }^{(13,21,29-32)}$.

Our study demonstrated that PG analogues induce less severe changes in the rabbit conjunctival epithelium than timolol maleate. In the group treated with timolol, there was a significant increase in conjunctival epithelial thickness and a marked increase of subepithelial collagen density, a finding that is consistent with the literature ${ }^{(13,18,21,24,29-30)}$. This finding may be secondary to epithelial cell edema, or to the presence of an inflammatory infiltrate, also found in greater intensity in timolol-treated eyes, and may partially explain the occurrence of dry eye symptoms in patients using timolol maleate. Several studies also demonstrated that timolol may induce a drop in goblet cells and a crystallization pattern associated with keratoconjunctivitis sicca ${ }^{(17,21,29)}$. Timolol has the larger decline of all drugs, but no significant differences were observed.

We observed a rise in goblet cells in the groups treated with PG analogues, a finding that was previously described for latanoprost ${ }^{(22-33)}$. However, our study is the first to confirm that the increase in goblet cells may also be observed with other PG analogues, such as travoprost and bimatoprost. Although the consequences of an increased goblet cell population remain unknown, we hypothesize that this finding may explain why the long-term use of PG analogues is associated with less severe dry eye symptoms than those induced by timolol maleate.

Our study also demonstrated a rise in blood vessels in the timolol and latanoprost groups. Interestingly, bimatoprost and travoprost, which were shown to induce conjunctival hyperemia in glaucomatous patients ${ }^{(4-5)}$, were not found to increase the number of blood vessels in the rabbit model.

A diffuse inflammatory infiltrate was noted in moderate intensity in the groups receiving PG analogues and in severe intensity in the timolol group, which also showed an increased subepithelial collagen density. The subclinical inflammation associated with the use of latanoprost was reported by others $^{(14,31)}$, who described inflammatory cells in the conjunctival epithelium and substantia propria, demonstrated by histopathological analysis as well as by immunohistochemical markers (HLA-DR, IL-6, IL-8). Our study suggests that the inflammatory infiltrate observed with the use of latanoprost is also found with other PG analogues. The finding of a dense inflammatory infiltrate in eyes using timolol maleate is in agreement with previous reports ${ }^{(13,20-21,24,29,34)}$.

It was shown that long-term topical treatment of glaucoma induces an increase in collagen deposition ${ }^{(14,35)}$. Mietz et al. ${ }^{(14)}$ investigated rabbits that used timolol, latanoprost, or the fixed combination of timolol and latanoprost for 18 months. At the end of the follow-up period, the conjunctiva showed an increased density of collagen fibers in the substantia propria of eyes treated with timolol and the fixed combination of timolol and latanoprost, but not in eyes treated with latanoprost alone. In our study, this finding was confirmed for timolol maleate and was detected earlier than in other reports $^{(14,35)}$. An up-regulation of matrix metalloproteinases may explain why PG analogues did not induce changes in collagen density. Metalloproteinases are essential to control tissue remodeling and may influence the scarring process of filtering blebs after glaucoma surgery ${ }^{(14-15,35-36)}$. Latanoprosttreated eyes showed an up-regulation of matrix metalloproteinases (MMP-3) and their tissue inhibitors (TIMP-2), leading to reduced extracellular accumulations of amorphous material in the conjunctiva.

Several studies suggested that the surgical outcome of trabeculectomy is less favorable in patients who received previous topical antiglaucoma therapy ${ }^{(13,19,24,28,37)}$. Broadway et al. $\mathrm{s}^{(19)}$ identified preoperative subclinical conjunctival inflammation induced by previous topical medication as a risk factor for failure of trabeculectomy. The reduction of success rates of glaucoma filtering procedures is probably due to the activation of fibroblasts from the conjunctiva, Tenon's, and episclera, leading to the formation of scar tissue surrounding the scleral flap ${ }^{(27,37)}$. The presence of an inflammatory infiltrate (induced by all antiglaucoma medications, 
but more severe in the timolol group) may induce fibroblast activation $^{(13,17,29,37)}$. Furthermore, the increased collagen density detected in the timolol group may already be a consequence of enhanced fibroblast activity.

Clinical, laboratory and experimental studies have suggested that conjunctival morphological changes were strongly associated with BAK, the most frequently used preservative in ophthalmic topical medications ${ }^{(16,38-39)}$. Pisella et al. ${ }^{(40)}$, using impression citology to compare toxicity of latanoprost and unpreserved or preserved timolol maleate, evaluated inflammatory markers and MUC5ACrelated mucin production in the conjunctiva of chronic users in a case-control ex-vivo study. Only patients treated for at least one year were included in this study and compared to normal subjects. HLA-DR, ICAM-1 and mucin were evaluated in a masked manner by flow citometry. For the in vitro study, a human conjunctiva derived cell-line was treated with $0.02 \%$ BAK-containing latanoprost or timolol, unpreserved timolol, or $0.02 \%$ BAK alone for 15 minutes, and cell viability and chromatin condensation were evaluated. These in vitro studies demonstrated that BAK-containing latanoprost and timolol exhibited higher proinflammatory and proapoptotic effects on conjunctival cells than unpreserved timolol. Latanoprost was found to induce fewer changes than preserved timolol, which is in agreement with our study.

The only study that investigated the effects of the three available PG analogues on the conjuntiva was reported by Guenoun et al. ${ }^{(32)}$. The authors performed in-vitro and exvivo experiments using human conjunctiva-derived cell lines to evaluate toxicity and expression of human inflammatory markers induced by PG analogues and BAK. PG analogues did not induce expression of inflammatory markers and even reduced the expression of ICAM-1 and PECAM-1 in the solutions with higher concentrations of BAK. The results of the previously described studies ${ }^{(32,40)}$ suggest a protective effect of PG analogues against preservative (BAK) toxicity due to possible antioxidative properties.

Contrary to the literature available, the present investigation was not able to detect marked conjunctival changes in the BAK group. This discrepancy may be due to short exposure time to the preservative in our study, to its low concentration in the solution used $(0.006 \%$ compared to other studies that used $0.02 \%$ ), or to the association of BAK and hypromellose and dextran 70 in artificial tears ${ }^{(41)}$.

In conclusion, although a moderate, diffuse inflammatory infiltrate was observed in PG-treated eyes, no changes in conjunctival epithelial thickness or subconjunctival collagen density were observed with these medications, suggesting that these drugs induce fewer changes than timolol maleate in the rabbit conjunctiva. Further studies are needed to investigate the influence of PG analogues versus other classes of antiglaucoma medications on the success rates of eyes undergoing trabeculectomy.

\section{RESUMO}

Objetivos: Comparar alterações histológicas induzidas por medicação anti-glaucomatosa na conjuntiva de coelhos. Métodos: Cinqüenta coelhos da raça Nova Zelândia foram divididos em 5 grupos de 10 animais. Os olhos esquerdos foram tratados com uma gota diária de bimatoprosta $0,03 \%$, travoprosta $0,004 \%$, latanoprosta $0,005 \%$, maleato de timolol $0,5 \%$ ou lágrimas artificiais contendo cloreto de benzalcônio (BAK) por 30 dias. Os olhos direitos serviram como controles. Foram realizadas biópsias conjuntivais límbicas superiores no $8^{\circ}$ e $30^{\circ}$ dias em 5 coelhos de cada grupo. A conjuntiva foi fixada com formaldeído $10 \%$, seguido por coloração de HE e PAS. Foi realizada análise quantitativa morfohistométrica para avaliar os seguintes parâmetros: infiltrado inflamatório, espessura epitelial, número de células caliciformes, diâmetro e número de vasos sanguíneos. Resultados: No $8^{\circ}$ e $30^{\circ}$ dias de tratamento, todos os grupos, exceto aquele que recebeu lágrimas artificiais, exibiram infiltrado inflamatório difuso, composto por linfócitos e neutrófilos, sendo mais denso no grupo timolol do que nos grupos dos análogos de prostaglandinas. No $30^{\circ}$ dia, o grupo timolol apresentou um aumento na densidade de colágeno subepitelial e um aumento significativo da espessura epitelial $(p=0,0035)$. A densidade de células caliciformes aumentou significativamente no $8^{\circ}$ dia no grupo tratado com travoprosta $(p=0,0006)$, e no $30^{\circ}$ dia nos grupos tratados com bimatoprosta $(p=0,0021)$ e latanoprosta $(p=0,009)$. Conclusões: Embora tenha sido observado um infiltrado inflamatório difuso e moderado nos olhos tratados com análogos de prostaglandinas, não houve alterações na espessura epitelial conjuntival ou densidade colágena subepitelial com essas medicações, sugerindo que essas drogas induzem menores alterações que o maleato de timolol na conjuntiva de coelhos.

Descritores: Prostaglandinas sintéticas; Timolol/uso terapêutico; Conjuntiva; Glaucoma/quimioterapia; Coelhos

\section{REFERENCES}

1. Gordon MO, Beiser JA, Brandt JD, Heuer DK, Higginbotham EJ, Johnson CA, et al. The Ocular Hypertension Treatment Study: baseline factors that predict the onset of primary open-angle glaucoma. Arch Ophthalmol. 2002;120(6):714-20; discussion 829-30. Comment in: Arch Ophthalmol. 2004;122(7):1088-9; author reply 1089 .

2. Ritch R, Shields B, Krupin T. Pharmacology. In: Ritch R, Shields MB, Krupin T, editors. The glaucomas. $2^{\text {nd }}$ ed. St. Louis: Mosby; c1996. v.3. p.1375-489.

3. Lindén C. Therapeutic potential of prostaglandin analogues in glaucoma. Expert Opin Investig Drug. 2001;10(4):679-94.

4. Noecker RS, Dirks MS, Choplin N. Bimatoprost/Latanoprost Study Group. Comparison of latanoprost, bimatoprost, and travoprost in patients with elevated intraocular pressure: a 12-week, randomized, masked-evaluator multicenter study. Am J Ophthalmol. 2003;137(1):210-1

5. Parrish RK, Palmberg P, Sheu WP; XLT Study Group. A comparison of latanoprost, bimatoprost, and travoprost in patients with elevated intraocular pressure: a 12-week, randomized, masked-evaluator multicenter study. Am J Ophthalmol. 2003;135(5):688-703. 
6. Stewart WC, Kolker AE, Stewart JA, Leech J, Jackson AL. Conjunctival hyperemia in healthy subjects after short-term dosing with latanoprost, bimatoprost, and travoprost. Am J Ophthalmol. 2003;135(3):314-20.

7. Feldman RM. Conjunctival hyperemia and the use of topical prostaglandins in glaucoma and ocular hypertension. J Ocul Pharmacol Ther. 2003;19(1):23-35.

8. Johnstone MA. Hypertrichosis and increased pigmentation of eyelashes and adjacent hair in the region of the ipsilateral eyelids of patients treated with unilateral topical latanoprost. Am J Ophthalmol. 1997;124(4):544-7.

9. Kook MS, Lee K. Increased eyelid pigmentation associated with use of latanoprost. Am J Ophhtalmol. 2000;129(6):804-6.

10. Pfeiffer N, Griesrson I, Goldsmith H, Hochgesand D, Winkgen-Böhres A, Appleton P. Histological effects in the iris after 3 months of latanoprost therapy: the Mainz 1 study. Arch Ophthalmol. 2001;119(2):191-6.

11. Teus MA, Arranz-Márquez E, Lucea-Suescun P. Incidence of iris colour change in latanoprost treated eyes. Br J Ophthalmol. 2002;86(10):1085-8.

12. Arcieri ES, Santana A, Rocha FN, Guapo GL, Costa VP. Blood-aqueous barrier changes after the use of prostaglandin analogues in patients with pseudophakia and aphakia: a 6-month randomized trial. Arch Ophthalmol. 2005; 123(2):186-92.

13. Brandt JD, Wittpenn JR, Katz LJ, Steinmann WN, Spaeth GL. Conjunctival impression cytology in patients with glaucoma using long-term topical medication. Am J Ophthalmol. 1991;112(3):297-301.

14. Mietz H, Shlötzer-Schrehardt U, Strassfeld C, Krieglstein GK. Effect of latanoprost and timolol on the histopathology of the rabbit conjunctiva. Invest Ophthalmol Vis Sci. 2001;42(3):679-87.

15. Mietz H, Esser JM, Welsandt G, Kociok N, Hueber A, Joussen A, et al. Latanoprost stimulates secretion of matrix metalloproteinases in tenon fibroblasts both in vitro and in vivo. Invest Ophthalmol Vis Sci. 2003;44(12): 5182-8.

16. Costagliola C, Prete AD, Incorvaia C, Fusco R, Parmeggiani F, Di Giovanni A. Ocular surface changes induced by topical application of latanoprost and timolol: a short-term study in glaucomatous patients with and without allergic conjunctivitis. Graefes Arch Clin Exp Ophthalmol. 2001;239(11): 809-14.

17. Herreras JM, Pastor JC, Calonge M, Asensio VM. Ocular surface alteration after long-term treatment with antiglaucomatous drug. Ophthalmology. 1992; 99(7):1082-8. Comment in: Ophthalmology. 1993;100(3):293-4.

18. Broadway DC, Grierson I, O’Brien C, Hitchings RA. Adverse effects of topical antiglaucoma medication. I. The conjunctival cell profile. Arch Ophthalmol. 1994;112(11):1437-45.

19. Broadway DC, Grierson I, O’Brien C, Hitchings RA. Adverse effects of topical antiglaucoma medication. II. The outcome of filtration surgery. Arch Ophthalmol. 1994;112(11):1446-54. Comment in: Arch Ophthalmol. 1995;113(7):849-50.

20. Lavin MJ, Wormald RP, Migdal CS, Hitchings RA. The influence of prior therapy on the success of trabeculectomy. Arch Ophthalmol. 1990;108(11): 1543-8.

21. Baudouin C, Garcher C, Haouat N, Bron A, Gastaud P. Expression of inflammatory membrane markers by conjunctival cells in chronically treated patients with glaucoma. Ophthalmology. 1994;101(3):454-60.

22. Aragona P, Candela V, Caputi AP, Micali A, Puzzolo D, Quintieri M. Effects of a stable analogue of PGE2 (11-deoxy-13,14-didehydro-16 (S)methylester methyl PGE2: FCE 20700) on the secretory processes of conjunctival globet cells of rabbit. Exp Eye Res. 1987;45(5):647-54.

23. Baudouin C. Side effects of antiglaucomatous drugs on the ocular surface. Curr Opin Ophthalmol. 1996;7(2):80-6.

24. Baudouin C, Pisella PJ, Fillacier K, Goldschild M, Becquet F, De Saint Jean $\mathrm{M}$, Béchetoille A. Ocular surface inflammatory changes induced by topical antiglaucoma drugs: human and animal studies. Ophthalmology. 1999; 106(3):556-63. Comment in: Ophthalmology. 1999;106(10):1853.

25. Blondin C, Hamard P, Cholley B, Haeffner-Cavaillon N, Baudouin C. In vitro effects of preserved or preservative-free antiglaucoma medications on human complement system. Curr Eye Res. 2003;27(4):253-9.

26. Broadway D, Hitchings R, Grierson I. The effect of topical anti-glaucomatous medications on the cell profile of the conjunctiva. Curr Opin Ophthalmol. 1993;4:51-7.

27. Addicks EM, Quigley HA, Green WR, Robin AL. Histologic characteristics of filtering blebs in glaucomatous eyes. Arch Ophthalmol. 1983;101(5):795-8.

28. Gwynn DR, Stewart WC, Pitts RA, McMillan TA, Hennis HL. Conjunctival structure and cell counts and the results of filtering surgery. Am J Ophthalmol. 1993;116(4):464-8.

29. Sherwood MB, Grierson I, Millar L, Hitchings RA. Long-term morphologic effects of antiglaucoma drugs on the conjunctiva and Tenon's capsule in glaucomatous patients. Ophthalmology. 1989;96(3):327-35.

30. Mietz H, Niesen U, Krieglstein GK. The effect of preservatives and antiglaucomatous medication on the histopathology of the conjunctiva. Graefes Arch Clin Exp Ophthalmol. 1994;232(9):561-5.

31. Bensoussan L, Blondin C, Baudouin C, Hamard P, Sabeh Afaki G, CreuzotGarcher C, et al. [Flow cytometric analysis of HLA-DR, IL-6 and IL-8 expression by conjunctival epithelial cells from patients with prolonged topical antiglaucoma treatments]. J Fr Ophtalmol. 2003;26(8):782-9. French.

32. Guenoun JM, Baudouin C, Rat P, Pauly A, Warnet JM, Brignole-Baudouin F. In vitro study of inflammatory potential and toxicity profile of latanoprost, travoprost, and bimatoprost in conjunctiva-derived epithelial cells. Invest Ophthalmol Vis Sci. 2005;46(7):2444-50.

33. Moreno M, Villena A, Cabarga C, Sanchez-Font E, Garcia-Campos J. Impression cytology of the conjunctival epithelium after antiglaucomatous treatment with latanoprost. Eur J Ophthalmol. 2003;13(6):553-9.

34. Guglielminetti E, Barabino S, Monaco M, Mantero S, Rolando M. HLA-DR expression in conjunctival cells after latanoprost. J Ocul Pharmacol Ther. 2002;18(1):1-9.

35. Broadway D, Hitchings R, Grierson I. Topical antiglaucoma therapy: adverse effects on the conjunctiva and implications for filtration surgery. J Glaucoma. 1995;4:136-48.

36. Oh DJ, Martin JL, Williams AJ, Peck RE, Pokorny C, Russell P, et al. Analysis of expression of matrix metalloproteinases and tissue inhibitors of metalloproteinases in human ciliary body after latanoprost. Invest Ophthalmol Vis Sci. 2006;47(3):953-63.

37. Young LT, Higginbotham EJ, Zou XL, Farber MD. Effects of topical glaucoma drugs on fistulized rabbit conjunctiva. Ophthalmology. 1990; 97(11):1423-7.

38. De Saint Jean M, Brignole F, Bringuier AF, Bauchet A, Feldmann G, Baudouin C. Effects of benzalkonium chloride on growth and survival of Chang conjunctival cells. Invest Ophthalmol Vis Sci. 1999;40(3):619-30.

39. Bensoussan L, Blondin C, Baudouin C, Hamard P, Sabeh Afaki G, CreuzotGarcher C, et al. [Flow cytometric analysis of HLA-DR, IL-6 and IL-8 expression by conjunctival epithelial cells from patients with prolonged topical antiglaucoma treatments]J Fr Ophtalmol. 2003;26(8):782-9. French.

40. Pisella PJ, Debbasch C, Hamard P, Creuzot-Garcher C, Rat P, Brignole F, Baudouin C. Conjunctival proinflammatory and proapoptotic effects of latanoprost and preserved and unpreserved timolol: an ex vivo and in vitro study. Invest Ophthalmol Vis Sci. 2004;45(5):1360-8.

41. Debbasch C, De La Salle SB, Brignole F, Rat P, Warnet M, Baudouin C. Cytoprotective effects of hyaluronic acid and Carbomer 934P in ocular surface epithelial cells. Invest Ophthalmol Vis Sci. 2002;43(11):3409-15. 